\title{
EVALUATION OF SINGLE TRACKS OF 17-4PH STEEL MANUFACTURED AT DIFFERENT POWER DENSITIES AND SCANNING SPEEDS BY SELECTIVE LASER MELTING
}

\author{
N.W. Makoana ${ }^{1 \#}$, H. Moller ${ }^{1}$, H. Burger ${ }^{1}$, M. Tlotleng$^{1}$ \& I. Yadroitsev ${ }^{2}$
}

\section{ARTICLE INFO}

\section{Article details}

Presented at the $17^{\text {th }}$ annual

international conference of the Rapid

Product Development Association of

South Africa (RAPDASA), held from 2-4

November 2016 in Vanderbijlpark,

South Africa

Available online

11 Nov 2016

\section{Contact details}

Corresponding author nmakoana@csir.co.za

\section{Author affiliations}

1 Council for Scientific and Industrial Research, National Laser Centre, Pretoria, South Africa

2 Department of Mechanical and Mechatronic Engineering, Central University of Technology, Free State, South Africa

\# The author was enrolled for a part-time MSc degree in the Department of Mechanical and Mechatronic Engineering, Central University of Technology, and is a contracted employee of the CSIR in Pretoria.

DOI

http://dx.doi.org/10.7166/27-3-1668

\section{ABSTRACT}

In Selective Laser Melting, the initial units produced are single tracks that overlap to create a single layer; from the sequence of layers, a 3D object is manufactured. The properties of the parts produced by SLM depend heavily on the properties of each single track and each layer formed by these tracks. This study evaluates the effect of processing parameters on the geometrical characteristics of single tracks manufactured from 17-4PH stainless steel powder. A single-mode continuous-wave ytterbium fibre laser was used to manufacture single tracks at laser powers in the range of $100-300 \mathrm{~W}$ with a constant spot size of $\sim 80 \mu \mathrm{m}$. The single tracks produced were subjected to standard metallographic preparation techniques for further analysis with an optical microscope. Deep molten pool shapes were observed at low scan speeds, while shallow molten pool shapes were observed at high scan speeds. At higher laser power densities, under-cutting and humping effects were also observed. The dimensions of single tracks processed without powder generally decrease with increasing scan speed at constant laser power. However, the geometrical features of the single tracks processed with powder revealed pronounced irregularities believed to be caused by non-homogeneity in the deposited powder layer.

\section{OPSOMMING}

Selektiewe lasersmelting produseer enkel bane wat mekaar oordek en vorm so ' $n$ enkele laag. Daaropvolgende lae vorm dan 'n driedimensionele onderdeel. Die eienskappe van hierdie onderdele word grootliks beïnvloed deur die eienskappe van elke baan en elke laag. Hierdie studie evalueer die effek van die prosesseringsparameters op die geometriese eienskappe van enkel bane wat van $17-4 \mathrm{PH}$ vlekvrye staalpoeier vervaardig is. 'n Enkelmodus kontinuegolf ytterbium vesel laser is gebruik om die enkel bane te vervaardig. Die laser drywing het gewissel van 100 tot $300 \mathrm{~W}$ met ' $\mathrm{n}$ konstante kolgrootte van ongeveer $80 \mu \mathrm{m}$. Die enkel bane is dan aan standaard metallografiese voorbereidingstegnieke onderwerp sodat verdere analise met 'n optiese mikroskoop kon geskied. Diepgesmelte poel vorms is bespeur teen lae skandeersnelhede, terwyl vlakgesmelte poel vorms by hoë skandeersnelhede gewaar is. By hoër laser drywingsdigthede is ondersnyding en hobbelvorming waargeneem. Die dimensies van die enkel bane wat sonder poeier geprosesseer is, het oor die algemeen afgeneem met 'n toename in skandeersnelheid by konstante laserdrywing. Die geometriese eienskappe van die enkel bane wat wel met poeier geprosesseer is, het noemenswaardige onreëlmatighede aan die lig gebring. Daar word vermoed dat die onreëlmatighede as gevolg van nie-homogene verskynsels in die gedeponeerde poeierlaag is. 
Selective laser melting (SLM), also known as powder bed fusion (PBF) or direct metal laser sintering (DMLS), is an additive manufacturing process that uses a laser beam to melt powder particles in order to produce 3D structures layer-by-layer directly from a 3D CAD model. The CAD model is generated with computer software and then sliced into a finite number of layers. Based on this information, a computer-controlled laser beam selectively scans the powder bed according to a 2D cross-section of each layer in order to fuse the powder particles. The initial units produced are single tracks that create a single layer; from the sequence of layers a 3D object is manufactured [1]. The ability of this technology to create parts layer-by-layer means that complex geometries can be easily optimised and produced without the need for hard tooling. Forms can be created that would be impractical or unachievable in other processes. This technology is optimised for low-volume, highvalue production, thus ensuring that the process is highly attractive for the aerospace and medical industries, among others. In the aerospace industry, part designs are optimised for low weight and high strength; thus SLM provides the design freedom that is missing from traditional manufacturing methods.

Current additive manufacturing processes have a number of limitations that inhibit widespread use of the technology in the aerospace industry [2]. This includes the processing time of the current state-of-the-art technology. The processing time is divided into primary and auxiliary process times. The primary time is mainly the time needed to melt each single layer, whereas operations like a lowering of the substrate and powder deposition are part of the auxiliary process time [3].The main influencing variables of the primary process time are layer thickness, scanning speed, and hatch spacing.

According to Yadroitsev et al. [5], the properties of parts manufactured by additive manufacturing depend a great deal on the properties of each single track and each layer, and on the strength of the connections between them. Numerous factors (direct and indirect parameters) affect the SLM process. However, the principal factors that affect the SLM process are laser power, wavelength, spot size, scanning speed, hatch spacing, and powder layer thickness [6].

Stainless steel $17-4 \mathrm{PH}$ is a precipitation hardening alloy that is characterised by an outstanding combination of high strength, good corrosion resistance, and good mechanical properties up to $300^{\circ} \mathrm{C}$. Because of these attractive properties, this alloy is widely-used in the aerospace industry to produce components that require high strength and good corrosion properties at high temperatures. Although the SLM parts of 17-4PH have been studied before, most published work focuses on the microstructure and the mechanical properties of 3D parts.

Averyanova et al. [11] investigated the effect of processing parameters on single tracks and single layers manufactured from $17-4 \mathrm{PH}$, using the experimental design approach to a maximum laser power of $50 \mathrm{~W}$ and a constant spot size of $\emptyset 70 \mu \mathrm{m}$. However, no work has been done to evaluate single tracks of $17-4 \mathrm{PH}$ processed at laser powers and spot sizes beyond these. Schleifenbaum et al. [4] and Yadroitsava et al. [6] highlighted that the application of high-power lasers and big spot size increases the build rate of SLM. Thus the aim of this study is to evaluate the geometrical characteristics of single tracks of $17-4 \mathrm{PH}$ steel processed at higher laser powers and bigger spot size.

\section{MATERIALS AND METHODS}

\subsection{Powder material}

Stainless steel 17-4PH powder supplied by EOS $\mathrm{GmbH}$ was used to conduct the experiments, with the nominal composition of the powder as follows: $\mathrm{Cr} 15.0-17.5 \%$, Ni $3.0-5.0 \%$, Cu $3.0-5.0 \%$, Si $1.0 \%$ $\max , \mathrm{Mn} 1.0 \% \max , \mathrm{C} 0.07 \% \max , \mathrm{Nb}$ and $\mathrm{Ta} 0.15 \% \max , \mathrm{P} 0.04 \% \max$, and $\mathrm{S} 0.03 \% \max$. The powder was gas-atomised, and most particles were found to have a high sphericity and smooth surfaces (Figure 1).

The particle size distribution was determined using Microtac Bluewave/S3500-SDC, a laser diffraction particle size analyser. The $10^{\text {th }}, 50^{\text {th }}$, and $90^{\text {th }}$ percentiles of equivalent diameters were $D_{10}=26.3 \mu \mathrm{m}, D_{50}=35.5 \mu \mathrm{m}$, and $D_{90}=52.8 \mu \mathrm{m}$. The substrates used in the experiments had a similar composition to that of the powder. 

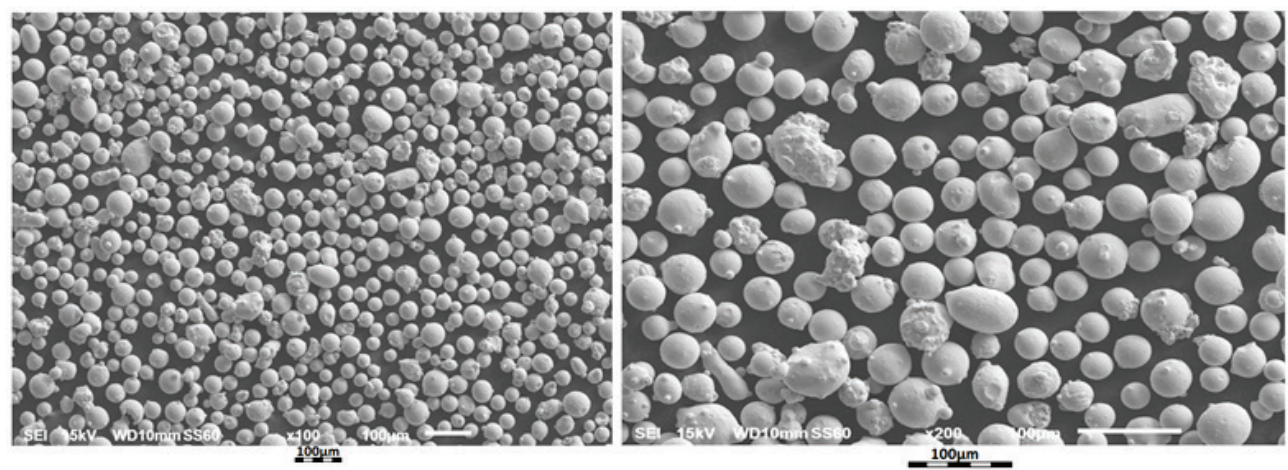

Figure 1: SEM micrographs of 17-4PH powder at different magnifications

\subsection{Experimental procedure}

An EOSINT M280 system equipped with a single-mode continuous-wave Ytterbium fibre laser, operating at $1075 \mathrm{~nm}$ wavelength and spot size of $80 \mu \mathrm{m}$, was used to produce single tracks at different laser powers and scan speeds $\left(19.9-59.7 \mathrm{~kW} / \mathrm{mm}^{2}\right)$ on the $17-4 \mathrm{PH}$ substrate. The processing chamber was filled with a nitrogen protective atmosphere to minimise oxidation. Table 1 shows the parameters that were employed.

Table 1: Design of the experiments.

\begin{tabular}{|c|c|c|c|c|}
\hline Laser power, W & 100 & 150 & 200 & 300 \\
\hline \multirow{9}{*}{ 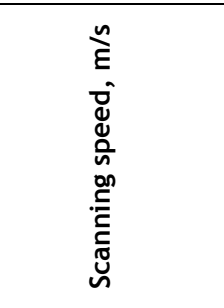 } & 0.4 & 0.6 & 0.8 & 1.2 \\
\hline & 0.5 & 0.8 & 1 & 1.4 \\
\hline & 0.6 & 1 & 1.2 & 1.6 \\
\hline & 0.7 & 1.2 & 1.4 & 1.8 \\
\hline & 0.8 & 1.4 & 1.6 & 2 \\
\hline & 0.9 & 1.5 & 1.8 & 2.2 \\
\hline & 1 & 1.6 & 2 & 2.4 \\
\hline & 1.2 & 1.8 & 2.2 & 2.6 \\
\hline & 1.4 & 2 & 2.4 & 2.8 \\
\hline
\end{tabular}

The powder layer thickness was kept constant at $50 \mu \mathrm{m}$. The single tracks manufactured were subjected to standard metallographic preparation techniques for further analysis with an optical microscope. Modified Fry's reagent $\left(150 \mathrm{ml} \mathrm{H} \mathrm{H}_{2} \mathrm{O}+50 \mathrm{ml} \mathrm{HCl}+25 \mathrm{ml} \mathrm{HNO}{ }_{3}+1 \mathrm{~g} \mathrm{CuCl}_{2}\right)$ was used to reveal the microstructure at the cross-sections of the single tracks.

\section{RESULTS AND DISCUSSION}

\subsection{Laser melting of the substrate}

The substrate was first scanned with the laser beam without powder in order to evaluate the effect of the processing parameters shown in Table 1 on the geometry of SLM tracks. There are two distinctive modes in laser processing: conduction and keyhole modes. The main difference between these two modes is the power density (power/spot size area) applied to the processing area. In conduction mode, the power density applied is insufficient to cause significant vaporisation; heat is absorbed from the laser beam through the top surface of the metal. In keyhole mode, however, the power density is high enough not only to vaporise material, but also to open a hole in the melt pool [7]. The conduction mode is also characterised by a semi-cylindrical shape, while the keyhole or penetration mode is characterised by a deep narrow shape [8].

According to Yadroitsava et al. [6], laser power density and scanning speed play a significant role in the geometry and shape of the molten pool. The laser power density defines the temperature gradient, and the scanning speed determines the time of laser-matter interaction. Figure 2 shows cross-sections of SLM tracks processed at different laser powers. It can been seen that increasing the laser power at a constant scanning speed $(1.4 \mathrm{~m} / \mathrm{s})$ results in deeper penetration $(21.0-75.4$ $\mu \mathrm{m})$ and increased material displacement and removal. This is in accordance with the increased energy input per unit area. 
The morphology of the SLM tracks processed at a constant laser power was affected by the change in scanning speed. This is mainly because the laser-material interaction time, related to the heat input, is decreased when increasing scanning speed, thus affecting the energy input per unit length. At low laser power (i.e., $100 \mathrm{~W}$ ), the keyhole mode and a deep molten pool was observed at a low scan speed of $0.4 \mathrm{~m} / \mathrm{s}$ (Figure 3 ). Higher laser powers above $100 \mathrm{~W}$ and scanning speeds above $1 \mathrm{~m} / \mathrm{s}$ result in defects, as shown in Figure 4. The SLM tracks processed at the highest laser power revealed a severe undercut and humping effect.

Generally, the track width and penetration depth decreases as the scanning speed is increased at a constant laser power (Figure 5). This is in accordance with the decreased heat input at higher scanning speeds. This also implies that the amount of energy transferred into the material decreases as the scanning speed increases, thus reducing the size of the molten pool.

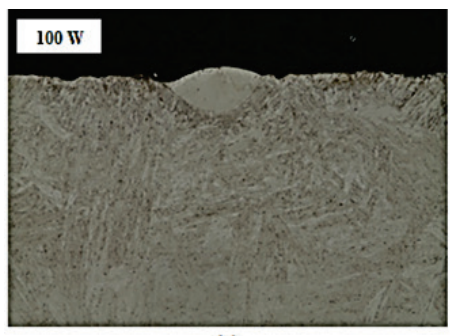

(a)

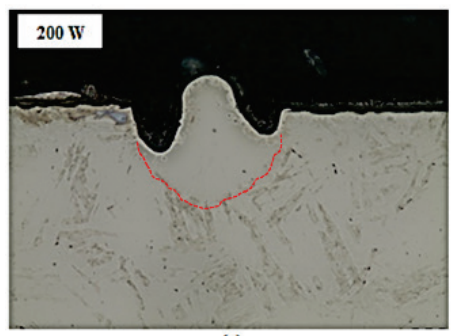

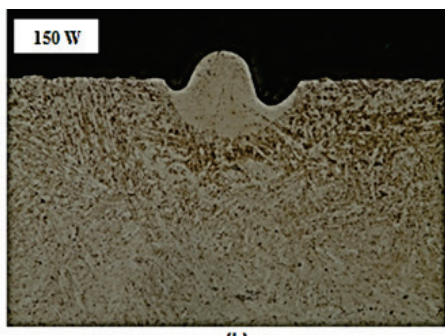

(b)

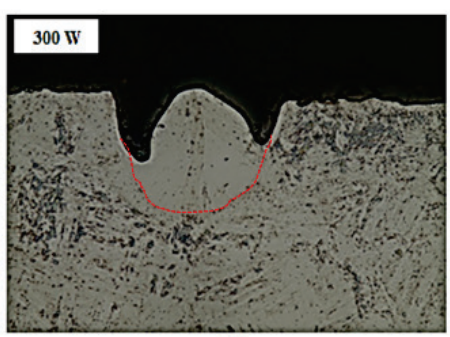

(d)

Figure 2: Cross-sections of SLM tracks processed at different laser powers and the same scanning speed $(1.4 \mathrm{~m} / \mathrm{s})$
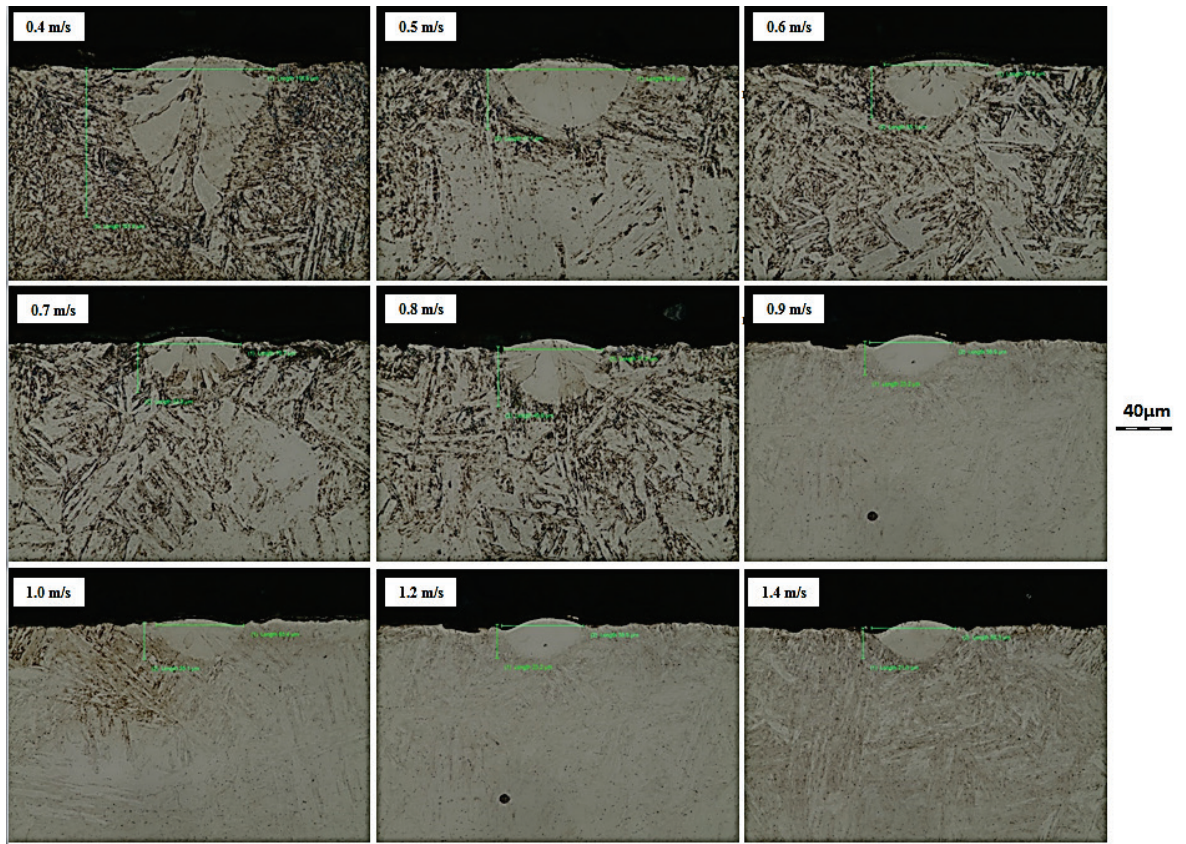

Figure 3: Cross-sections of SLM tracks processed at constant laser power (100 W) and varying scanning speeds 


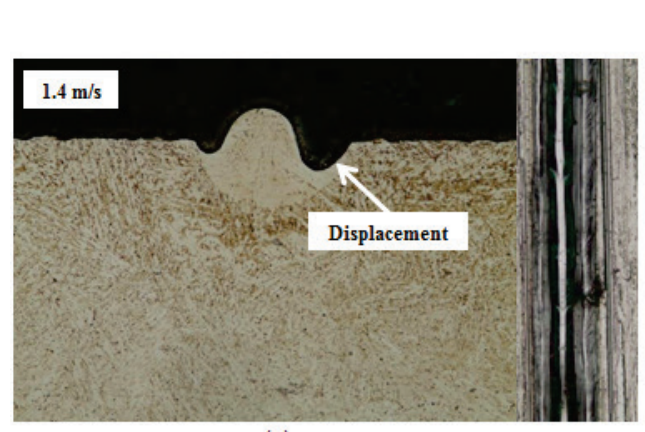

(a)

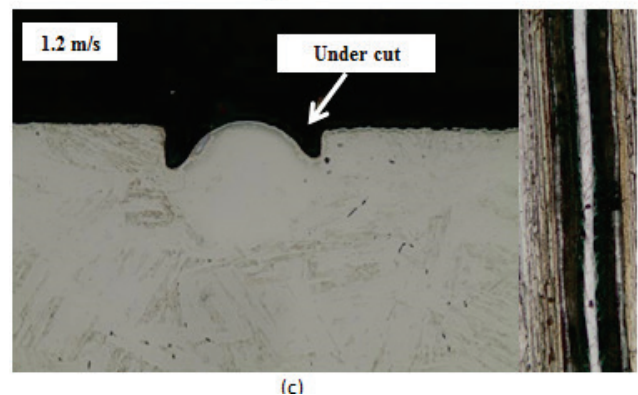

(c)

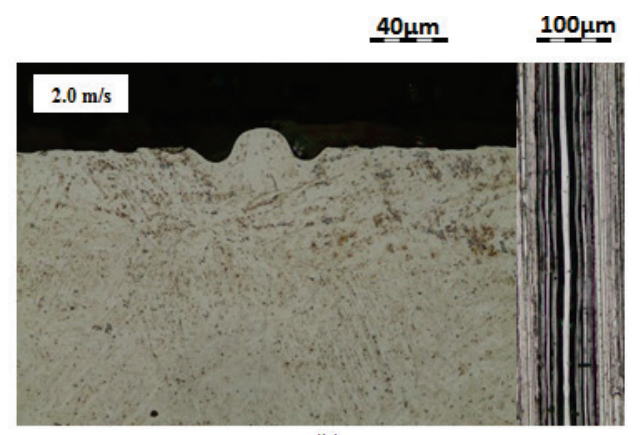

(b)

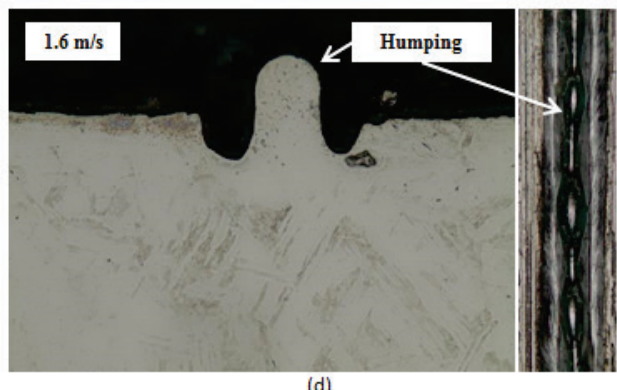

(d)

Figure 4: Cross-sections and top view images of SLM tracks processed at different laser powers and scanning speeds: (a) \& (b) $150 \mathrm{~W}$; (c) \& (d) $300 \mathrm{~W}$

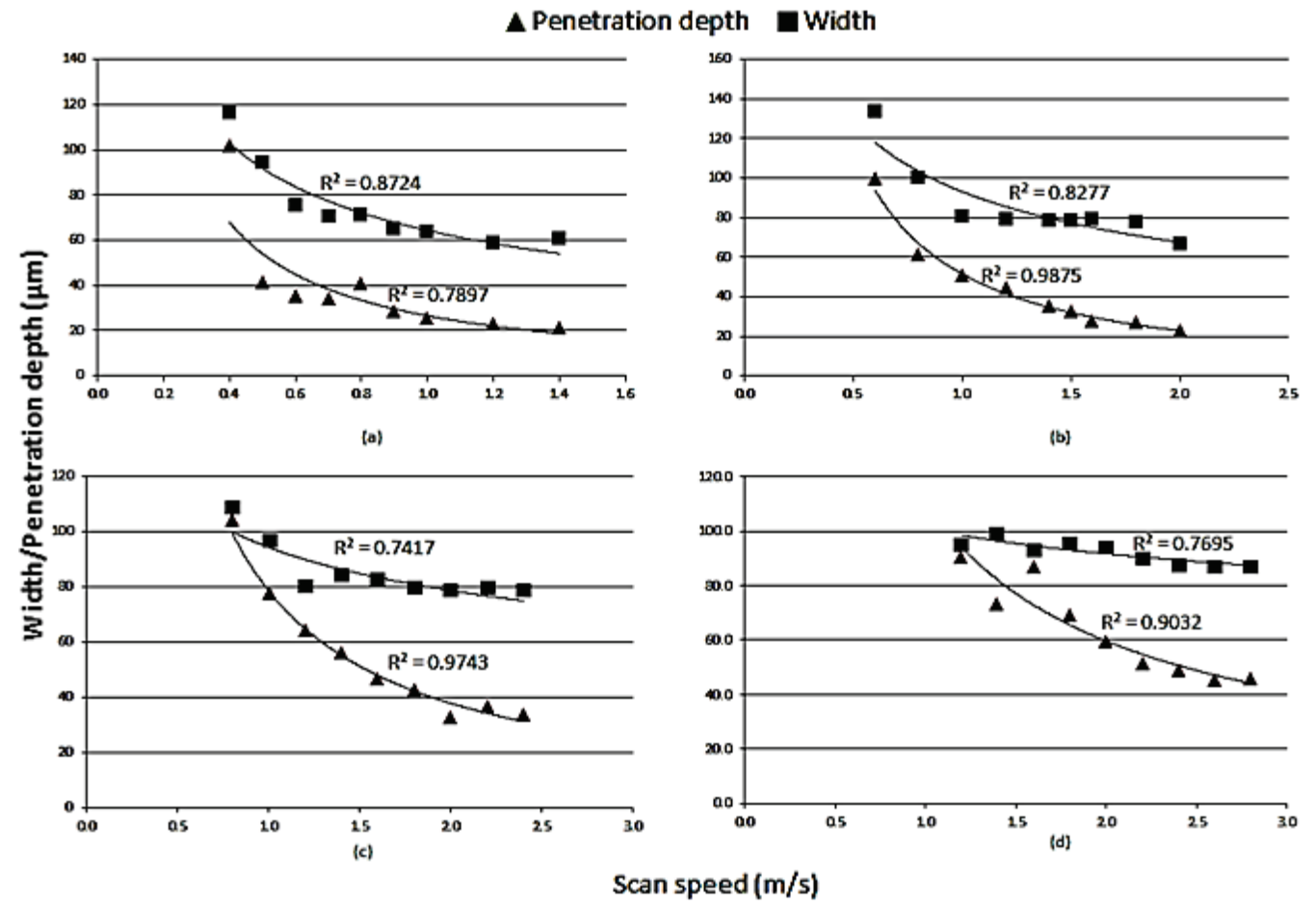

Figure 5: Width and penetration depth of SLM tracks processed at different laser powers of (a) $100 \mathrm{~W}$; (b) $150 \mathrm{~W}$; (c) $200 \mathrm{~W}$; and (d) $300 \mathrm{~W}$

\subsection{Laser melting of powder}

The essential operation of SLM is the laser beam scanning over the surface of a deposited powder layer in order to create a melt pool. As a result, the geometrical characteristics of single tracks processed from powder depend a great deal on the volume of material involved in the process [6]. In the second part of the experiments, the deposited powder layer was scanned with a laser beam 
in order to evaluate the geometrical characteristics of single tracks processed at different laser power and scanning speeds.

The effect of laser power on the geometrical characteristics of single tracks was analysed by comparing single tracks processed at a constant scanning speed $(1.4 \mathrm{~m} / \mathrm{s})$. As in laser melting of the bulk material, increasing the laser power increases the energy input per unit area and thus increases the size of the molten pool (Figure 6). At a high laser power density, the input energy was also sufficient to cause significant vaporisation (Figures $6 c$ \& d).

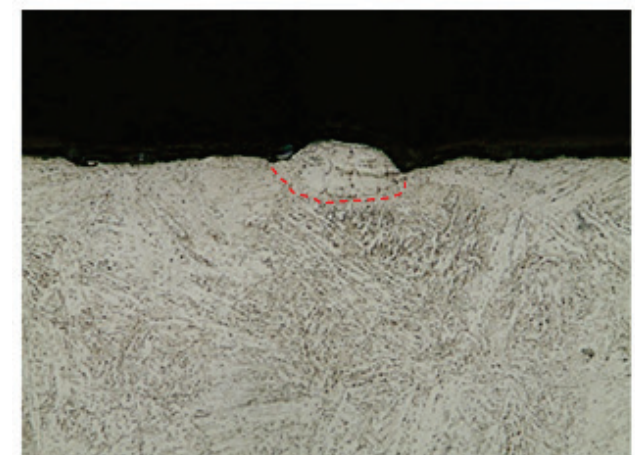

(a)

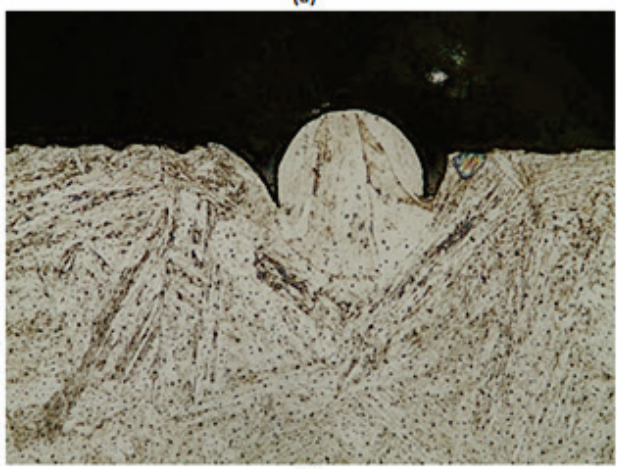

(c)

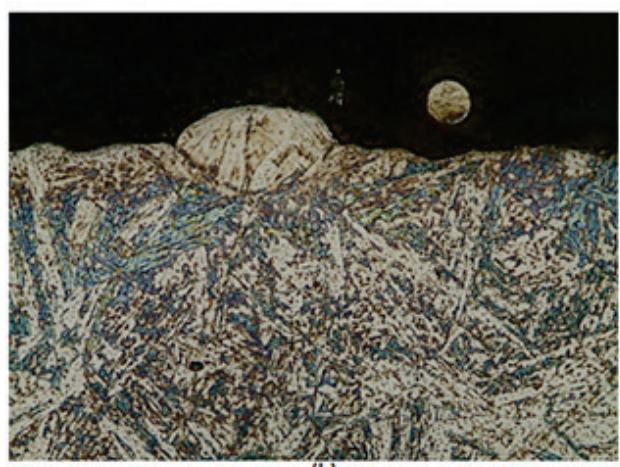

(b)

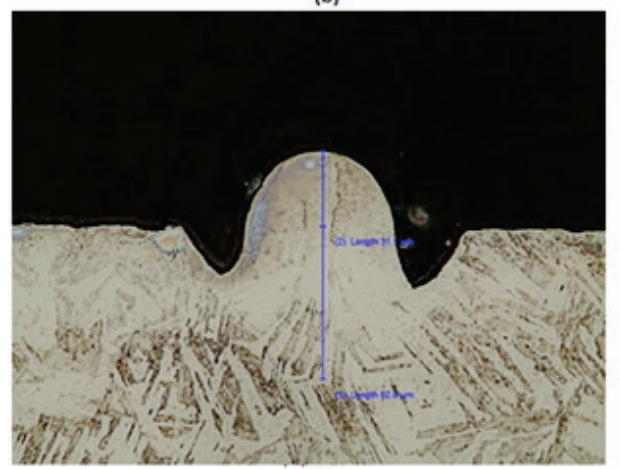

(d)

Figure 6: Cross-sections of single tracks processed at constant scanning speed and different laser powers: (a) $100 \mathrm{~W}$; (b) $150 \mathrm{~W}$; (c) $200 \mathrm{~W}$; and (d) $300 \mathrm{~W}$

The effect of scanning speed on the morphology of single tracks processed at constant laser power $(100 \mathrm{~W})$ was also evaluated (Figure 7$)$. Generally, the track width and penetration depth decreases with increasing scan speed. The variation in track height was higher due to irregularities in the powder layer deposited on the substrate. A humping effect was observed at higher laser powers $(>150 \mathrm{~W})$ and scan speeds $(>1.4 \mathrm{~m} / \mathrm{s})$. In addition, satellites were observed on the surface of some of the scanned tracks. Yadroitsev et al. [10] defined a satellite as a particle sticking to the surface of the scanned track that formed by spattering or partial re-melting of the powder in the peripheral zone of the laser spot. Re-melting of the sintered layers can help to reduce the number of satellites in 3D SLM objects.

The correlation between track dimensions and processing parameters (i.e., laser power and scanning speed) is graphically demonstrated in Figure 8. The coefficients of determination ( $R^{2}$ values) for both track width and penetration depth decreases with increasing laser power, while the $\mathrm{R}^{2}$ values for track height are low at all laser powers, except at $150 \mathrm{~W}$ where the track height is seen to increase with increasing scanning speed. These irregularities are believed to be caused by the nonhomogeneity in the deposited powder layer and chaotic melt pool hydrodynamics at higher laser powers. The results also demonstrate that the layer thickness should be chosen according to the powder particle size. 

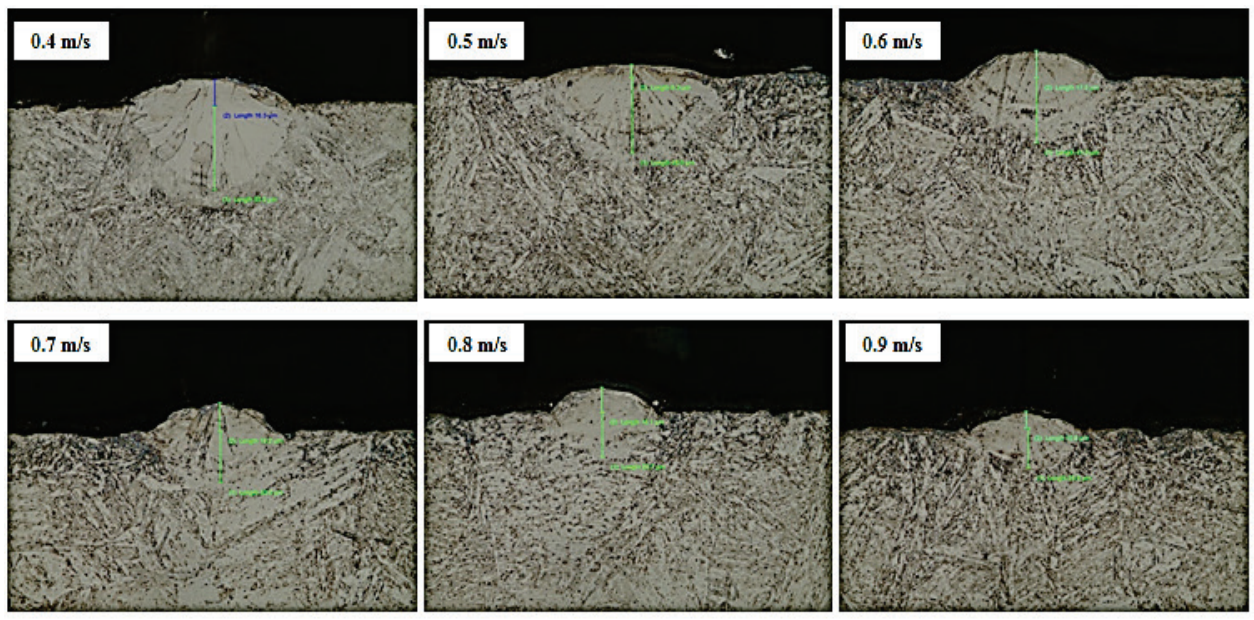

$40 \mu \mathrm{m}$
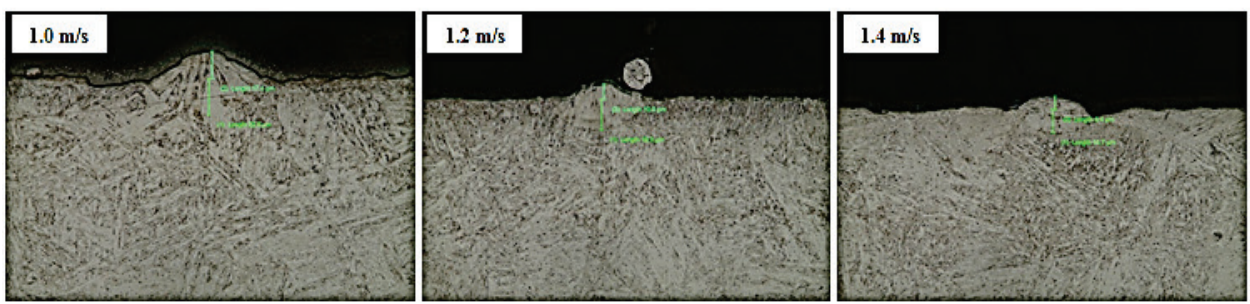

Figure 7: Single tracks processed at low laser power (100 W) and varying scanning speeds

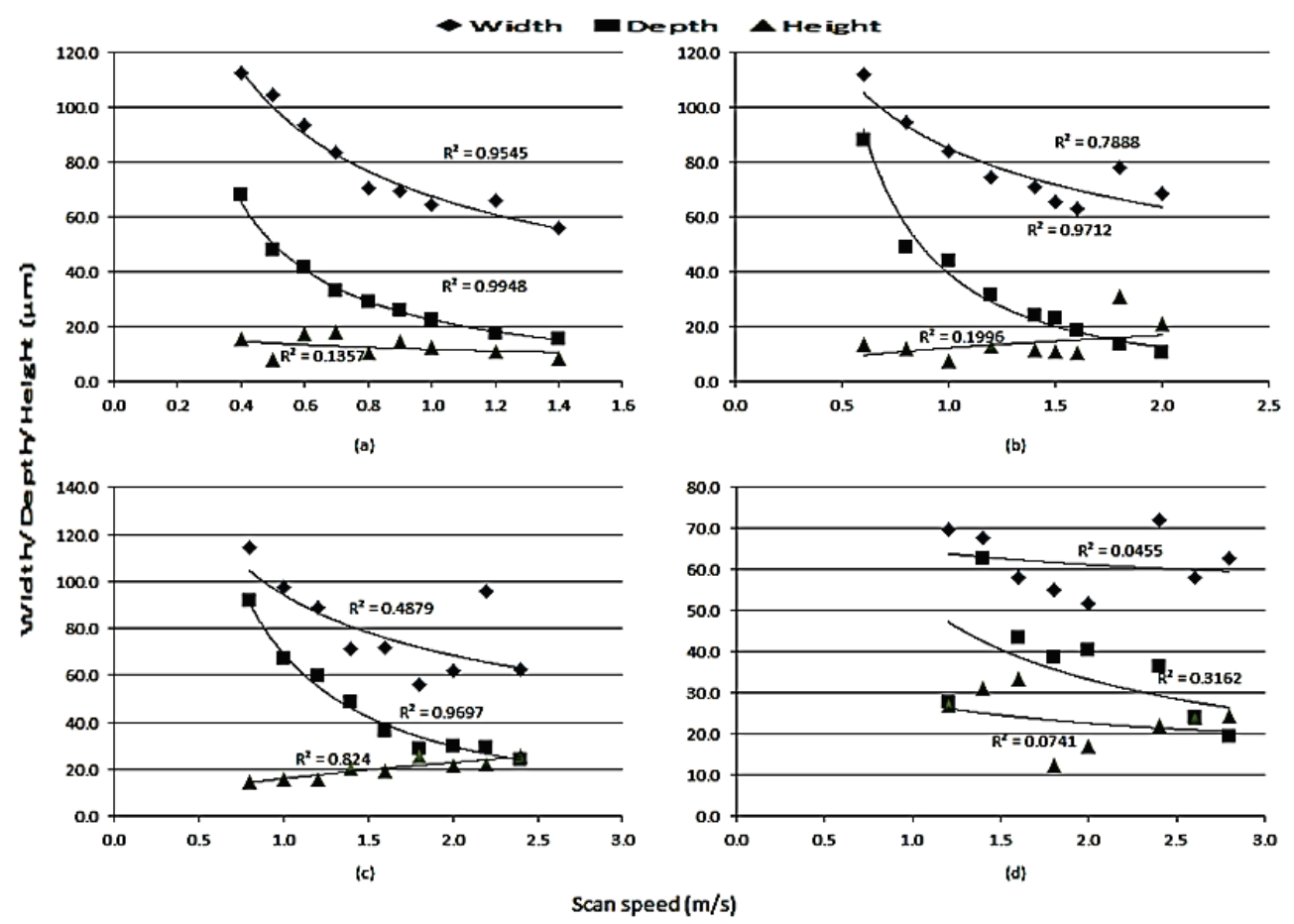

Figure 8: Track width, penetration depth, and height as a function of scanning speed at different laser powers: (a) $100 \mathrm{~W}$; (b) $150 \mathrm{~W}$; (c) $200 \mathrm{~W}$; and (d) $300 \mathrm{~W}$

The cohesion between successive layers plays an important role in the mechanical properties of SLM parts [6]. This is primarily dependent on the powder layer thickness and penetration depth. The penetration depth in this case refers to the depth of penetration into the substrate material/ previously sintered layer (re-melted depth). According to Kempen et al. [12], each synthesised layer must penetrate the layer below enough to successfully produce a consolidated single track. When 
the penetration depth is reduced at low laser power and high scan speeds, the chance of insufficient bonding between layers increases, while at high laser powers and low scan speeds, the deep molten pool and evaporation can provoke the formation of pores in the manufactured parts.

Therefore, our requirements for the SLM track to be included in the optimal process window are:

- $\quad$ The track must be continuous;

- $\quad$ The track must penetrate the previous layer enough to accomplish good cohesion of the layers (wetting of the layer underneath); and

- $\quad$ The track must be high enough to build up the part.

However, irregularities in the geometrical features of single tracks processed with powder make it difficult to draw any inferences about the optimal process window.

\section{CONCLUSIONS}

In this study, single tracks of $17-4 \mathrm{PH}$ steel processed at different laser powers and scanning speeds were evaluated. The results led to the following conclusions:

1) The dimensions (width and penetration depth) of single tracks processed with and without powder generally decrease with an increasing scan speed at a constant laser power;

2) Higher laser power densities provoke the formation of undercut and humping defects (with and without powder);

3) At constant laser power, keyholes with a deep molten pool shape were observed at low scanning speeds (with and without powder); and

4) Non-homogeneity in the deposited powder layer increases the variation in track dimensions (irregularities).

\section{FUTURE WORK}

Laser melting of powder should be repeated using fine powder $\left(D_{90}=45 \mu \mathrm{m}\right)$, in order to improve the homogeneity of the deposited layer. It is believed that delivering a homogeneous layer will minimise irregularities in track morphology and track dimensions, and thus allow for the determination of an optimal process window.

An evaluation of single tracks processed at higher laser powers $(>900 \mathrm{~W})$ and bigger spot size $(\varnothing 240$ $\mu \mathrm{m})$ is needed. Laser power densities (laser power/spot area) should be maintained (19.9$59.7 \mathrm{~kW} / \mathrm{mm}^{2}$ ) in order to make comparisons and identify the peculiarities of upscaling SLM of 17 $4 \mathrm{PH}$ steel.

\section{ACKNOWLEDGEMENTS}

This work was made possible by the support of the Central University of Technology and Aeroswift (collaborative work between the CSIR, Aerosud, and the Department of Science and Technology

\section{REFERENCES}

[1] Yadroitsev, I. and Smurov, I. 2010. Selective laser melting technology: From the single laser melted track stability to 3D parts for complex shape. Physics Procedia, 5(2), pp. 551-560.

[2] Keck, W. and Warner, M. 2016. The significance of selective laser melting in commercial aircraft jet engine components. University of Pittsburgh Swanson School of Engineering. Retrieved from http://136.142.82.187/eng12/temp/papers/6236.docx. (Accessed: 18 August 2016).

[3] Matilainen, V., Piili, H., Salminen, A., Syvänen, T. and Nyrhila, O. 2014. Characterization of process efficiency improvements in laser additive manufacturing. Physics Procedia, 56(c), pp. 317-326.

[4] Schleifenbaum, H., Diatlov, A., Hinke, C., Bültmann, J. and Voswinckel, H. 2011. Direct photonic production: Towards high speed additive manufacturing of individualized goods. Production Engineering, 5(4), pp. 359-371.

[5] Yadroitsev, I., Gusarov, A., Ydroitsava, I. and Smurov, I. 2010. Single track formation in selective laser melting of metal powders. Journal of Materials Processing Technology, 210(12), pp. 1624-1631. 
[6] Yadroitsava, I., Els, J., Booysen, G. and Yadroitsev, I. 2015. Peculiarities of single track formation from Ti6AL4V alloy at different laser power densities by selective laser melting. South African Journal of Industrial Engineering, 26(3), pp. 86-95.

[7] Assuncao, E., William, S. and Yapp, D. 2012. Interaction time and beam diameter effects on the conduction mode limit. Optics and Lasers in Engineering, 50(6), pp. 823-828.

[8] Walsh, C.A. 2002. Laser welding - Literature review. Materials Science and Metallurgy Department, University of Cambridge, England. Retrieved from http://www.msm.cam.ac.uk/phasetrans/2011/laser_Walsh_review.pdf. (Accessed: 22 August 2016).

[9] Aboulkhair, N.T., Maskery, I., Tuck, C., Ashcroft, I. and Everitt, N.M. 2016. On the formation of AlSi10Mg single tracks and layers in selective laser melting: Microstructure and nano-mechanical properties. Journal of Materials Processing Technology, 230(2016), pp. 88-98.

[10] Yadroitsev, I., Krakhmalev, P., Yadroitsava, I., Johansson, S. and Smurov, I. 2013. Energy input effect on morphology and microstructure of selective laser melting single track from metallic powder. Journal of Materials Processing Technology, 213(4), pp. 606-613.

[11] Averyanova, M., Cicala, E., Bertrand, P. and Grevey, D. 2012. Experimental design approach to optimize selective laser melting of martensitic 17-4 PH powder: Part I - Single laser tracks and first layer. Rapid Prototyping Journal, 18(1), pp. 28-37.

[12] Kempen, K., Thijs, L., Yasa, E., Badrossamay, M., Verheecke, W. and Kruth, J.P. 2011. Process optimization and microstructural analysis for selective laser melting of AlSi10Mg. In: Proceedings of Annual International Solid Freeform Fabrication Symposium, Texas, USA, pp. 484-495. 